\title{
A Study on Water Resource Allocation in Jiaokou Irrigation Area
}

\author{
Li Mengna ${ }^{1}$, Liu Rui ${ }^{2}$, Qian Hui ${ }^{1, *}$, and Meng Xiangyi ${ }^{1}$ \\ ${ }^{1}$ School of Environmental Science and Engineering, Chang'an University, Xi'an, China \\ ${ }^{2}$ Powerchina Xibei Engineering Corporation Limited, Xi'an, China
}

\begin{abstract}
To solve the current problems occurred in Jiaokou irrigation area, and to realize sustainable utilization of water resources, this article proposes several water resource allocation plans, based on water supply and demand calculation in the area. A model is used to simulate these plans. The results shows that using groundwater and surface water at the ratio of 2:1 during spring and winter irrigation time, the maximum drawdown is about 10m after 50 years. Considering Hanjiang-to-Weihe River Water Transfers Project, if water quality of Weihe River recovers in 2040, it will take 20 years to recover the water level. If water quality of Weihe River recovers in 2050, it will take 30 years to recover the water level. After recovery of water level, a final allocation plan is proposed to prevent salinization.
\end{abstract}

\section{Introduction}

China's vast territory and complicated natural conditions lead to notable interannual and interdecadal changes of water resources, which resulted in frequent floods and droughts, and a scant supply of water in dry years and seasons. Since the 1970s, water shortage in agriculture, industry and cities has become a widespread phenomenon. From 1959 to 2010, average annual drought farmland covers an area of $2.323 \times 10^{5} \mathrm{~km}^{2}$ [1]. Currently, there are more than 300 Chinese cities facing the problem of water shortage due to various reasons, and the area of farmland without irrigation has reached $6.7 \times 10^{4} \mathrm{~km}^{2}$. According to a preliminary forecast, China's water deficit will reach 100 billion $\mathrm{m}^{3}$ by 2030 [2]. In the year 2013 for China, $63.4 \%$ water is used for agriculture, $22.7 \%$ for industry, $12.2 \%$ for life, and $1.7 \%$ for ecology. Compared with advanced countries, the proportion of agriculture use of water is bigger, and water use efficiency is low [3]. Therefore, reasonable allocation of water resources, which can alleviate the contradiction between supply and demand of water by controlling water resources distribution, is an important way to solve water crisis and realize the sustainable utilization of water [4].

\section{Study area}

Jiaokou irrigation district is located in mid-east Shaanxi Province, northwest China. The district's latitude ranges from $34^{\circ} 33^{\prime} 20^{\prime \prime}$ to $34^{\circ} 50^{\prime} 00^{\prime \prime} \mathrm{N}$, while its longitude ranges from $109^{\circ} 15^{\prime} 25^{\prime \prime}$ ' to $109^{\circ} 48^{\prime} 45^{\prime \prime} \mathrm{E}$, covering the irrigated area of approximately $842 \mathrm{~km}^{2}$ [5]. The irrigation water mainly comes from Weihe river. In recent years, water quality of Weihe river is becoming worse and worse due to the unreasonable development and utilization of river water, and the constantly discharge of industrial and domestic wastewater $[6,7]$. Unreasonable development and utilization of upstream Weihe river also causes an insufficient supply of irrigation water in summer. Because surface water is used for irrigation for a long time, groundwater level rises sharply. So waterlogging disasters may happen. Therefore, the objective of this study is to solve this problem by adopting proper water allocation plan.

\section{Calculation of water supply and demand}

A reasonable allocation of water resources plan should, first of all, meet crop water requirements. Based on irrigation quotas of different crops, total amount of required water in jiaokou during the irrigation period can be calculated. The total water demand is $1.4619 \times 10^{4} \mathrm{~m}^{3} / \mathrm{a}$. There are four main kinds of crops in the district, wheat, corn, cotton and fruit trees. Wheat, cotton and fruit trees are summer crops, while corn, cotton and fruit trees are autumn crops. Then, monthly water demand during the irrigation period can be calculated. Combined with the collected data, water supply and water demand is shown in table 1.

Table 1. Water supply and water demand $\left(10^{4} \mathrm{~m}^{3}\right)$

\begin{tabular}{|c|c|c|c|c|}
\hline Month & $\begin{array}{c}\text { Surface } \\
\text { water } \\
\text { supply }\end{array}$ & $\begin{array}{c}\text { Groundwater } \\
\text { supply }\end{array}$ & $\begin{array}{c}\text { Water } \\
\text { demand }\end{array}$ & Difference \\
\hline Jan. & 250.0 & 100.8 & 339.9 & 10.9 \\
\hline Feb. & 630 & 254 & 642.2 & 241.8 \\
\hline Mar. & 900 & 362.8 & 1153.7 & 109.1 \\
\hline Apr. & 1850.0 & 745.8 & 2345 & 250.8 \\
\hline May & 2268.0 & 914.3 & 2900 & 282.3 \\
\hline Jun. & 1445.0 & 582.5 & 2695.2 & -667.7 \\
\hline Jul. & 1445.0 & 582.5 & 2103.2 & -75.7 \\
\hline Aug. & 1445.0 & 582.5 & 1852.2 & 175.3 \\
\hline Nov. & 250 & 100.8 & 321.4 & 29.4 \\
\hline Dec. & 300 & 120.9 & 266.4 & 154.5 \\
\hline Total & 10783.0 & 4346.9 & 14619.2 & 510.7 \\
\hline
\end{tabular}

It can be seen that the total amount of irrigation water is sufficient. In spring (February, march, April and May) and winter (January, November, December) irrigation water is sufficient. But in summer irrigation water is insufficient. The shortage of water in June is $667.7406 \times 10^{4} \mathrm{~m}^{3}$, in July $75.7603 \times 10^{4} \mathrm{~m}^{3}$. This is caused by two reasons. First, there isn't enough flow in weihe river. Second, sediment concentration in river water is too high, which makes the irrigation system unable to work. 


\section{Water resource allocation}

\subsection{Allocation plan}

In recent years, water quality of Weihe river is becoming worse and worse. If Jiaokou uses it for a long time, groundwater may be polluted, and drinking water safety in the area will be influenced. So for the status quo of jiaokou irrigation area, moderately reducing the use of river water from weihe river, and increasing the exploitation of groundwater becomes necessary. Because it will not only protect groundwater in jiaokou district, but at the same time, when groundwater level declines, waterlogging disasters will be avoided.

As water quality of weihe river in wet season is slightly better, and summer irrigation water isn't enough, surface water must be used during summer irrigation to meet water requirement. So the scheme is proposed to reduce getting water from weihe river during spring and winter irrigation time.

\subsubsection{Scheme one}

Use groundwater during spring and winter irrigation time. See table 2.

Table 2. Water allocation plan (scheme one) $\left(10^{4} \mathrm{~m}^{3}\right)$

\begin{tabular}{|c|c|c|}
\hline Month & Surface water supply & Groundwater supply \\
\hline Jan. & 0 & 339.9 \\
\hline Feb. & 0 & 642.2 \\
\hline Mar. & 0 & 1153.7 \\
\hline Apr. & 0 & 2345 \\
\hline May & 0 & 2900 \\
\hline Jun. & 1445 & 1250.2 \\
\hline Jul. & 1445 & 658.2 \\
\hline Aug. & 1445 & 407.2 \\
\hline Nov. & 0 & 321.4 \\
\hline Dec. & 0 & 266.4 \\
\hline Total & 4335 & 10284.2 \\
\hline
\end{tabular}

\subsubsection{Scheme two}

Use groundwater and surface water at the ratio of 2:1 during spring and winter irrigation time. See table 3.

\subsection{Simulation}

The simulated area is bound to the west by Shichuanhe River, to the east by Luohe River, to the south by weihe River, and to the north by the edge of fuping-pucheng tableland. The water used to irrigate in the area is phreatic water, so the aquifer system is conceptualized as a layer, namely the unconfined aquifer.

To study the changes of groundwater level under different irrigation conditions, meteorological, hydrological, hydrogeological and other related data were collected. These data were used to establish a twodimensional transient model of groundwater in the study area. The result of model calibration and verification is acceptable.

Table 3. Water allocation plan (scheme two) $\left(10^{4} \mathrm{~m}^{3}\right)$

\begin{tabular}{|c|c|c|}
\hline Month & Surface water supply & Groundwater supply \\
\hline Jan. & 113.3 & 226.6 \\
\hline Feb. & 214.1 & 428.1 \\
\hline Mar. & 384.6 & 769.1 \\
\hline Apr. & 781.7 & 1563.3 \\
\hline May & 966.7 & 1933.3 \\
\hline Jun. & 1445 & 1250.2 \\
\hline Jul. & 1445 & 658.2 \\
\hline Aug. & 1445 & 407.2 \\
\hline Nov. & 107.1 & 214.3 \\
\hline Dec. & 88.8 & 177.6 \\
\hline Total & 6991.2 & 7628 \\
\hline
\end{tabular}

\subsubsection{Scheme one}

Running the established model for 50 years, the result shows that scheme one will resulted in a serious drawdown of water table .The maximum drawdown is more than $25 \mathrm{~m}$. Except floodplain, water depth in the area is bigger than $20 \mathrm{~m}$. According to previous research, when the maximum drawdown is small than half of the aquifer thickness [8], it's acceptable. Otherwise, it will cause problems such as groundwater exploitation difficulty and deterioration of groundwater quality. According to the collected data, aquifer thickness in jiaokou irrigation area ranges from $30 \mathrm{~m}$ to $50 \mathrm{~m}$. So $15 \mathrm{~m}$ is regarded as the maximum acceptable drop for groundwater level. In scheme one, the biggest drop is bigger than $15 \mathrm{~m}$, which means that this plan is not appropriate.

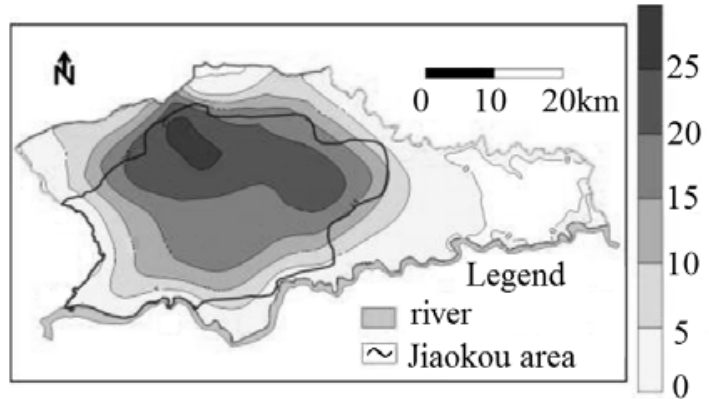

Figure 1. Drawdown of water table after 50 years (scheme one)

\subsubsection{Scheme two}

For scheme two, the maximum drawdown is about $10 \mathrm{~m}$ after 50 years. Buried depth of water table is generally between $5 \mathrm{~m}$ and $30 \mathrm{~m}$, which will not lead to salinization. According to field investigation in 2013, depths of most wells in jiaokou irrigation area are more than $40 \mathrm{~m}$, so the 
buried depth of water table is appropriate, and scheme two can be adopted.

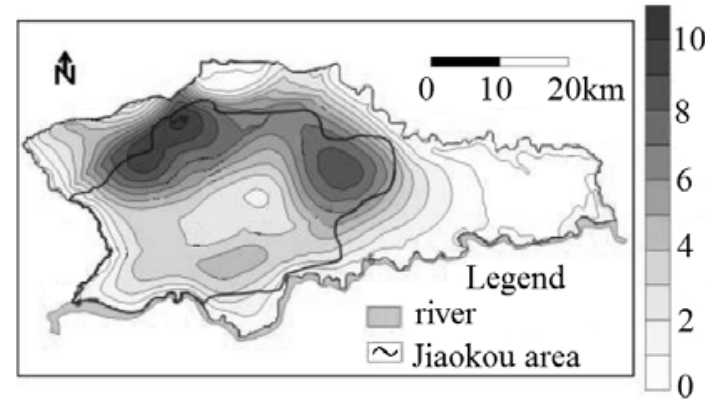

Figure 2. Drawdown of water table after 50 years (scheme two)

\section{Water resource allocation combined with Hanjiang-to-weihe river water transfers project}

In order to deal with the contradiction between supply and demand of water resources in Guanzhong Plain and to improve ecological environment of Weihe River, the shaanxi provincial government proposed Hanjiang-toWeihe River Water Transfers Project in 2008. The project draws water from Han River to supply water to Xi'an, Xianyang, Weinan and Tongchuan, so that ecological water of Weihe river can be back, which is helpful to improve the water quality of the river. It includes three phases: first phase, which is expected to be completed in 2020, diverts 1 billion $\mathrm{m}^{3}$ of water from Han River. Second phase, ended in 2025, diverts 500 million $\mathrm{m}^{3}$ of water. Third phase, accomplished in 2030, realize the diversion of 1.5 billion $\mathrm{m}^{3}$ of water.

Combined with the characteristics of Hanjiang-toWeihe River Water Transfers Project and the development tendency of jiaokou irrigation district, new schemes are put forward.

\subsection{Allocation plan}

When water quality of Weihe River is recovered, the first problem that should be resolved is the recovery of water table. This period of time is called the recovery period.

\subsubsection{Scheme one}

It's assumed that water quality of Weihe River will recover after 10 years of operation of Hanjiang-to-Weihe River Water Transfers Project (2040).

After 2040, surface water is used to irrigate in most times, groundwater is only used during summer irrigation time. Therefore, the plan proposed in 4.1.2 is used before 2040. After 2040, table 4 is used to allocate water resources.

\subsubsection{Scheme two}

It's assumed that water quality of Weihe River will recover after 20 years of operation of Hanjiang-to-Weihe River Water Transfers Project (2050).
Same as scheme one, the plan proposed in 4.1.2 is used before 2050. After 2050, table 5 is used to allocate water resources.

Table 4. Water allocation plan in recovery period (scheme one) $\left(10^{4} \mathrm{~m}^{3}\right)$

\begin{tabular}{|c|c|c|}
\hline Month & Surface water supply & Groundwater supply \\
\hline Jan. & 339.9 & 0 \\
\hline Feb. & 642.2 & 0 \\
\hline Mar. & 1153.7 & 0 \\
\hline Apr. & 2345 & 0 \\
\hline May & 2900 & 0 \\
\hline Jun. & 1445 & 1250.2 \\
\hline Jul. & 1445 & 658.2 \\
\hline Aug. & 1445 & 407.2 \\
\hline Nov. & 321.4 & 0 \\
\hline Dec. & 266.4 & 0 \\
\hline Total & 12303.6 & 2315.6 \\
\hline
\end{tabular}

Table 5. Water allocation plan in recovery period (scheme two) $\left(10^{4} \mathrm{~m}^{3}\right)$

\begin{tabular}{|c|c|c|}
\hline Month & Surface water supply & Groundwater supply \\
\hline Jan. & 239.1 & 100.8 \\
\hline Feb. & 388.2 & 254 \\
\hline Mar. & 790.9 & 362.8 \\
\hline Apr. & 1599.2 & 745.8 \\
\hline May & 1985.7 & 914.3 \\
\hline Jun. & 1445 & 1250.2 \\
\hline Jul. & 1445 & 658.3 \\
\hline Aug. & 1445 & 407.2 \\
\hline Nov. & 220.6 & 100.8 \\
\hline Dec. & 145.5 & 120.9 \\
\hline Total & 9704.2 & 4915.1 \\
\hline
\end{tabular}

\subsection{Simulation}

\subsubsection{Scheme one}

The plan is simulated by the model for 20 years. The result shows that water level drawdown is less than $1 \mathrm{~m}$ in most places compared to initial water level, which means the water level has been restored basically. 


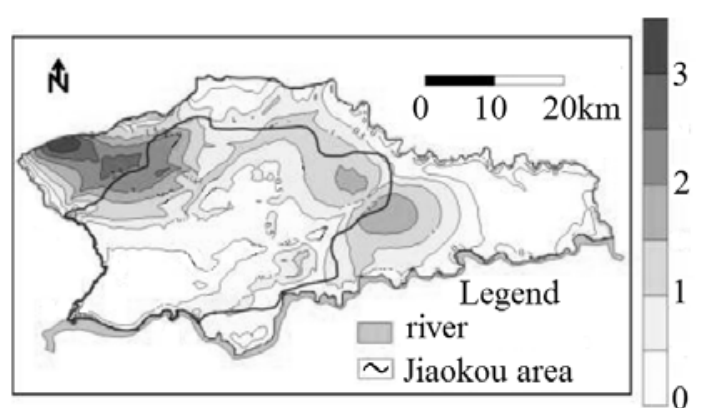

Figure 3. Drawdown of water table after 20 years (scheme one)

\subsubsection{Scheme two}

The plan is simulated by the model for 30 years. It's obvious that water level drawdown is less than $1 \mathrm{~m}$ in most places compared to initial water level, which means the water level has been restored basically.

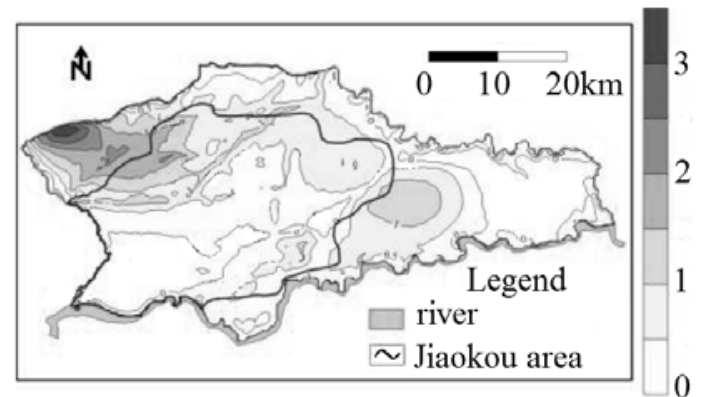

Figure 4. Drawdown of water table after 30 years (scheme two)

\subsection{After recovery period}

After the recovery of water level, a new water resources allocation scheme is needed to prevent secondary salinization. According to the simulation results before, the change of water level in 50 years is basically within $1 \mathrm{~m}$, with the trend of slightly downward. Therefore, after the recovery of water level, a new water resources allocation plan is put forward. See table 6 .

Table 6. Water allocation plan after recovery period $\left(10^{4} \mathrm{~m}^{3}\right)$

\begin{tabular}{|c|c|c|}
\hline Month & Surface water supply & Groundwater supply \\
\hline Jan. & 239.1 & 100.8 \\
\hline Feb. & 388.2 & 254 \\
\hline Mar. & 790.9 & 362.8 \\
\hline Apr. & 1599.2 & 745.8 \\
\hline May & 1985.7 & 914.3 \\
\hline Jun. & 1445 & 1250.2 \\
\hline Jul. & 1445 & 658.2 \\
\hline Aug. & 1445 & 407.2 \\
\hline Nov. & 220.6 & 100.8 \\
\hline Dec. & 145.5 & 120.9 \\
\hline Total & 9704.2 & 4915.1 \\
\hline
\end{tabular}

The new plan is adjusted from two aspects: 1 . Increase the exploitation of groundwater in summer irrigation time to meet the water requirement of crops. 2. In spring and winter irrigation time, reduce water diversion at head works. Table 1 shows that the current water supply exceeds crop water requirement more than $500 \mathrm{~m}^{3}$ each year. So this part of water is reduced to save water. Thus, not only water requirement of crops can be satisfied, but also water level will decrease.

Simulation result shows that after 50 years, water level will decrease for a certain degree. The maximum drawdown is about $5 \mathrm{~m}$. The buried depth is basically more than $3 \mathrm{~m}$. And water field is stable. So the plan is appropriate.

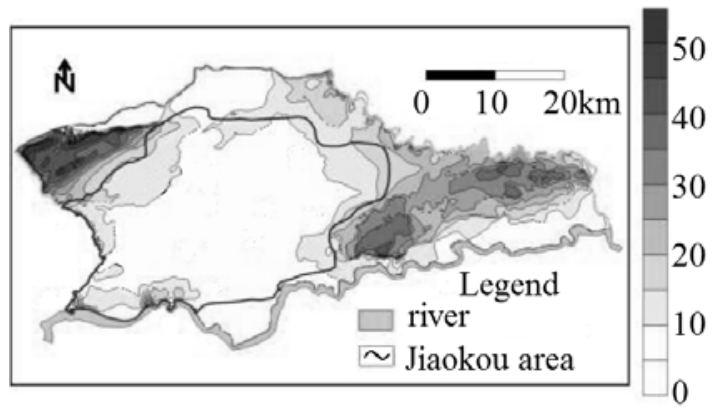

Figure 5. Buried depth of water table after 50 years

\section{Conclusions}

(1)Crop water requirement is calculated. Except September and October, water is needed to irrigate. Annual amount of irrigation water reaches $1.46 \times 108 \mathrm{~m}^{3}$.

(2)Water quality of Weihe river is becoming worse and worse. So in summer irrigation time, groundwater only supplies the insufficient part of surface water irrigation. Use groundwater and surface water at the ratio of 2:1 during spring and winter irrigation time. According to simulation, this scheme is feasible.

(3)Considering Hanjiang-to-Weihe River Water Transfers Project, if water quality of Weihe River recovers in 2040, it will take 20 years to recover the water level. If water quality of Weihe River recovers in 2050, it will take 30 years to recover the water level. After recovery of water level, a new allocation plan is proposed to prevent salinization. In the plan, excess amount of water is cut down and more groundwater is used to irrigate. According to simulation, water level meets the requirements of critical water level. The plan is adoptable.

\section{Acknowledgments}

This work is supported by the special Funds for Scientific Research on Public Interest of the Ministry of Water Resources (201301084).

\section{References}

[1] Zhou GS. The Meteorological and Environmental Sciences. 38, 80 (2015).

[2] Song Q. Research on allocation of water resources in Baojixia-Yangmaowan irrigation area,(2010). 
[3] He HS. Resource Development \& Market. 31, 816 (2015).

[4] Wang GX, Chen MJ. Journal of Water Resources and Water Engineering. 20, 1 (2009).

[5] Liu R. A study on water resource rational allocation in Jiaokou irrigation district,(2014).

[6] Zhu L, Li HE, Li JK, Gao F. Acta Scientiae Circumstantiae. 33, 885 (2013).

[7] Yu J, Li HE. Environmental Science. 34, 1700 (2013)

[8] Zhang CC, Shao JL, Li CJ, Cui YL. Journal of Changchun University of Science and Technology. 33, 323 (2003). 